\title{
Perceptions about the Therapeutic Itinerary after stroke: a qualitative research
}

\author{
Percepções sobre o Itinerário Terapêutico após acidente vascular cerebral: pesquisa qualitativa \\ Percepciones sobre el Itinerario Terapéutico después del ictus: investigación cualitativa
}

\section{Andreza Maria Luzia Baldo de Souza' ORCID: 0000-0002-6575-2209 \\ Rodrigo de Almeida Bastos' ORCID: 0000-0002-6159-8048 \\ Luciane Miranda Guerra' ORCID: 0000-0002-7542-7717 \\ Brunna Verna de Castro Gondinho" ORCID: 0000-0002-1061-4407 \\ Marcelo de Castro Meneghim 1 ORCID: 0000-0003-2673-3627 \\ Pedro Augusto Thiene Leme' ORCID: 0000-0003-3894-3189}

'Universidade Estadual de Campinas. Campinas, São Paulo, Brazil. "Universidade Estadual do Piauí. Parnaíba, Piauí, Brazil.

How to cite this article: Souza AMLB, Bastos RA, Guerra LM, Gondinho BVC, Meneghim MC, Leme PAT. Perceptions about the therapeutic itinerary after stroke: a qualitative research. Rev Bras Enferm. 2021;74(3):e20201140. https://doi.org/10.1590/0034-7167-2020-1140

\section{Corresponding author:}

Andreza Maria Luzia Baldo de Souza

E-mail:andrezamlb@gmail.com

EDITOR IN CHIEF: Antonio José de Almeida Filho ASSOCIATE EDITOR: Hugo Fernandes

Submission: 11-17-2020

Approval: 03-10-2021

\begin{abstract}
Objectives: to analyze the understanding of the Therapeutic Itinerary of people affected by stroke in the Unified Health System context of a medium-sized city in the state of São Paulo. Methods: this is a clinical-qualitative, using in-depth semi-structured interviews, conducted in 2019 with 6 patients, a number determined by theoretical saturation. Results: qualitative content analysis allowed the construction of four categories that emerged from the data: a) You are having a stroke! - Identifying the problem; b) Anguish and expectations in waiting for assistance; c) Helplessness and guidance for rehabilitation after hospital discharge; d) Spirituality in rehabilitation after stroke. Final Considerations: the affected people expressed feelings and meanings, such as fear, anguish, sadness, beliefs and uncertainties, in order to shed light on the complexity inherent to the experiences of Therapeutic Itinerary of stroke. Descriptors: Stroke; Rehabilitation; Qualitative Research; Attitude to Health; Emergency Treatment.
\end{abstract}

\section{RESUMO}

Objetivos: analisar a compreensão sobre o Itinerário Terapêutico de pessoas acometidas por acidente vascular cerebral no contexto do Sistema Único de Saúde de município de médio porte do estado de São Paulo. Métodos: clínico-qualitativo, com uso de entrevistas semiestruturadas em profundidade, realizadas em 2019, com 6 pacientes, número determinado pela saturação teórica. Resultados: a análise qualitativa de conteúdo permitiu a construção de quatro categorias que emergiram dos dados: a) Você está tendo um derrame! - A identificação do problema; b) Angústias e expectativas na espera por atendimento; c) $O$ desamparo e a orientação para reabilitação após a alta hospitalar; d) A espiritualidade na reabilitação após Acidente Vascular Cerebral. Considerações Finais: as pessoas acometidas expressaram sentimentos e significados, como medo, angústias, tristezas, crenças e incertezas, de forma a jogar luz sobre a complexidade inerente às experiências de Itinerário Terapêutico do acidente vascular cerebral.

Descritores: Acidente Vascular Cerebral; Reabilitação; Pesquisa Qualitativa; Atitude Frente a Saúde; Socorro de Urgência.

\section{RESUMEN}

Objetivos: analizar la comprensión del Itinerario Terapéutico de personas afectadas por ictus en el contexto del Sistema Único de Salud de una ciudad mediana del estado de São Paulo. Métodos: clínico-cualitativo, mediante entrevistas semiestructuradas en profundidad, realizadas en 2019, con 6 pacientes, número determinado por saturación teórica. Resultados: el análisis de contenido cualitativo permitió la construcción de cuatro categorías que surgieron de los datos: a) ¡Estás sufriendo un derrame cerebral! - La identificación del problema; b) Angustia y expectativa en espera de asistencia; c) Desamparo y orientación para la rehabilitación después del alta hospitalaria; d) Espiritualidad en la rehabilitación después de un ictus. Consideraciones Finales: las personas afectadas expresaron sentimientos y significados, como miedo, angustia, tristeza, creencias e incertidumbres, con el fin de arrojar luz sobre la complejidad inherente al Itinerario Terapéutico de las experiencias del ictus.

Descriptores: Accidente Cerebrovascular; Rehabilitación; Investigación Cualitativa; Actitud Frente a la Salud; Socorro de Urgencia. 


\section{INTRODUCTION}

Stroke is one of the world's leading causes of death, in addition to being responsible for sequelae, whose rehabilitation challenges health systems $\mathrm{s}^{(1-2)}$. It is recommended that rehabilitation be patientcentered and that therapy be as comprehensive as possible $\mathrm{e}^{(1,3)}$.

In Brazil, integrated actions against cerebrovascular diseases are foreseen in the Unified Health System (SUS - Sistema Único de Saúde). Among these actions, there are supports from primary care, with professionals trained in stroke identification, to emergency and referral hospital units. Outpatient and hospital rehabilitation continues this cycle of integrated support, with rear beds for complex chronic care, home care programs, and social reintegration ${ }^{(4)}$.

A current term called "Therapeutic Itineraries" encompasses all movements triggered by individuals or groups in the preservation or recovery of health, from home care and religious practices to conventional biomedical devices ${ }^{(1,5)}$. The movements that will compose a certain path and the forms of treatment reflect the individual and collective perceptions about the illness process" ${ }^{\prime \prime}(1,6)$. Understanding the Therapeutic Itineraries of stroke patients becomes of interest to the health system for the improvement of care, as it relates to decision making that materialize certain trajectories ${ }^{(7)}$.

It is assumed that such decisions and paths are governed by idiosyncrasies, in which individual aspects, socio-cultural representations concerning the disease and the healing systems, socioeconomic and structural conditions related to the availability of access compete. Each choice is made according to the situations and explanations culturally accepted by the group ${ }^{(8)}$. In this regard, different studies have recommended the incorporation of surviving patients' perspectives, within each socio-cultural context, for the improvement of lines of care ${ }^{(9-10)}$.

Literature usually associates appropriate responses to stroke events, with the ability to recognize risk factors, signs and symptoms. Thus, population surveys on the level of knowledge on the subject have been identified as important tools for preventive and educational programs $s^{(11)}$. However, such surveys, usually done through the application of closed questionnaires, end up producing results of questionable validity, evidencing the demand for qualitative studies ${ }^{(12)}$.

In this sense, it was evidenced, through closed questionnaires, that themes such as alternative or magical solutions to the stroke event, with the potential to delay the search for help, would be little shared by people in a given context. However, the qualitative deepening done with focus groups in the same population has shown that they are common attitudes ${ }^{(12)}$. In this sense, the gap to be filled has to do with the understanding of the therapeutic path based on patients' perceptions. They are people who experience the health system protocols and relationships that are not always harmonious with professionals and whose perceptions directly affect the therapeutic progress. Therefore, the question that guided this research was: what is the perception of SUS users, affected by stroke, about the therapeutic path experienced?

The physical and psychosocial consequences of stroke patients are dependent on the course unfolding, which may result in impairment of individuals' daily performance of activities ${ }^{(13)}$. For this reason, investigating the perceptions attributed by patients who have suffered a stroke, from assistance, through assistance to rehabilitation, has the potential to highlight the singularly perceived difficulties, offering important subsidies ${ }^{(1)}$ for the improvement of care proposals.

\section{OBJECTIVES}

To analyze the understanding of the Therapeutic Itinerary of people affected by stroke in the Unified Health System context of a medium-sized city in the state of São Paulo.

\section{METHODS}

\section{Ethical aspects}

The research project was submitted to the Research Ethics Committee of the Faculty of Dentistry of Piracicaba at Universidade Estadual de Campinas (FOP-UNICAMP), having been approved. The subjects were presented with the Informed Consent Form (ICF).

\section{Type of study}

This is a qualitative study, particularized by the Clinical-Qualitative Method (CQM), using the semi-structured in-depth interview technique ${ }^{(14)}$. The research report was verified and adjusted under the COREQ checklist criteria(15).

\section{Methodological procedures}

Initially, ambiance was carried out, that is, the researcher's permanence for a long period in the context of Family Health Units, and acculturation interviews with the usual ones (health team and patients), with free notes in the field diary, with a view to assimilation of the population's worldview. At this moment, the researcher raised, with the health teams, all the cases of registered patients who suffered a stroke in their respective territories, and sought them, in a non-systematized sequence, to make the invitation to participate.

Then, the semi-directed and in-depth interviews were scheduled according to participants'availability and preference, held in their own homes and in a reserved space. The interviews were conducted by the principal researcher, who underwent training with her advisor, in addition to having obtained support from the Qualitative Research Study Group (GEPEQ) of FOP-UNICAMP, both with expertise in research of this nature. Although the main researcher had no previous experience with interviews, her training as a physiotherapist anticipated the development of skills, such as listening and welcoming patients' anxieties, attributes valued in the context of the interviews within the CQM and related to the validity of the data obtained.

The interviews were initiated through the mutual re-presentation between interviewer and interviewee, with the concern of establishing rapport and asking the following triggering question: I would like you to tell me: how was your stroke? ${ }^{(1)}$ The free association of interviewees' ideas was valued, with the researcher's intervention in situations where the answers were incomplete or obscure, asking them, respectively, to speak more particularities or more clearly what was being said. Auxiliary questions were occasionally used in order to conduct the interview for the purposes, when necessary. As a complementary source of data, in addition to the verbal content, the researcher focused on detecting interviewees' global behavior, registered after the 
interview. Thus, personal presentation, non-verbal communication, laughter, embargoed speeches, silences, vacillations and lapses were noted and considered during interpretation of results, as well as the researcher's self-observation (countertransference).

\section{Study setting}

The study was conducted in a municipality in the countryside of São Paulo State, with an estimated population of 407,252 thousand inhabitants, with a high value for the Human Development Index $(\mathrm{HDI} ; 0.785)^{(16)}$. Individuals who suffered ischemic or hemorrhagic strokes, who lived in the municipality in areas covered by Family Health Strategy (FHS), during the study period were included. Aphasic individuals and/or those with severe cognitive impairment, measured through the previous application of the Mini Mental State Examination (MMSE) instrument were excluded. The interviews were conducted between January and May 2019.

\section{Data source}

The intentional sample closure was determined by theoretical saturation. Thus, the collection was suspended when, in the researcher's assessment, new information would add little to the development of the objectives under study, having been obtained the number of 6 interviewees ${ }^{(17)}$.

\section{Data collection and organization}

The main data, from the interviews, were audio recorded using a recorder, transcribed through basic text editing applications and by the researcher herself. Secondary data, from the stages of acclimatization and acculturation and observation of the interviews, were recorded in a handwritten form.

\section{Data analysis}

The data obtained were treated by the qualitative content analysis technique. This technique consists of seven sequential and interdependent steps (Figure 1) ${ }^{(14)}$ :

\begin{tabular}{|c|c|c|}
\hline $\begin{array}{l}\text { (a) Transcript of } \\
\text { recorded interviews }\end{array}$ & $\begin{array}{l}\text { (f) Definition of the } \\
\text { categories in an }\end{array}$ & \\
\hline & way, to refine the material & by peers and \\
\hline $\begin{array}{l}\text { (b) Rereading of } \\
\text { transcripts and audio } \\
\text { using text skimming, } \\
\text { touching the text } \\
\text { without anxiety to } \\
\text { mark responses }\end{array}$ & $\begin{array}{l}\text { (e) Presentation and } \\
\text { discussion of material } \\
\text { with peers during work } \\
\text { meetings }\end{array}$ & $\begin{array}{l}\text { group of } \\
\text { specialists in the } \\
\text { field of Applied } \\
\text { Psychology } \\
\text { and Preventive }\end{array}$ \\
\hline & \multirow[b]{2}{*}{$\begin{array}{l}\text { (d) Categorization and } \\
\text { subcategorization, } \\
\text { grouping statements } \\
\text { of respondents of } \\
\text { similar significance, } \\
\text { and highlighting } \\
\text { significant discourses } \\
\text { for understanding the } \\
\text { hypothesis formulated, } \\
\text { forming nuclei of meaning }\end{array}$} & $\begin{array}{l}\text { FOP-UNICAMP, } \\
\text { accustomed to }\end{array}$ \\
\hline $\begin{array}{l}\text { (c) Elaboration of } \\
\text { comments and } \\
\text { impressions emerging } \\
\text { from this fluctuating } \\
\text { reading, written in the } \\
\text { right margin of the } \\
\text { transcribed data }\end{array}$ & & qualitative research \\
\hline
\end{tabular}

Note: FOP-UNICAMP - Faculty of Dentistry of Piracicaba, Universidade Estadual de Campinas. Figure 1 - Flowchart of qualitative content analysis ${ }^{(1)}$
All peers, for category judgment and validation, were attentive to the heterogeneity between the categories, internal homogeneity to the categories and coherence of the title of each category with their central ideas ${ }^{(1,14)}$. The product of the "seven steps" were four categories of analysis, discussed from the dialogue between understanding the reality, experienced in the field by the researcher, and the comparison with preexisting literature (books and articles correlated to the theme/research problem) ${ }^{(14)}$.

\section{RESULTS}

\section{Sample description}

The sociodemographic data of the 6 interviewees are described in Chart 1.

Chart 1 - Sample characterization

\begin{tabular}{|c|c|c|c|c|c|c|}
\hline Participants & Age & Sex & Education & $\begin{array}{l}\text { Marital } \\
\text { status }\end{array}$ & $\begin{array}{l}\text { Ictus type } \\
\text { and time }\end{array}$ & MMSE \\
\hline S1 & 70 & $\mathrm{~F}$ & Illiterate & Widowed & $\begin{array}{l}\text { Ischemic, } 7 \\
\text { years old }\end{array}$ & 22 \\
\hline S2 & 57 & $M$ & $\begin{array}{l}\text { Incomplete } \\
\text { elementary } \\
\text { school }\end{array}$ & Divorced & $\begin{array}{l}\text { Ischemic, } 1 \\
\text { year old }\end{array}$ & 29 \\
\hline S3 & 21 & $\mathrm{~F}$ & $\begin{array}{l}\text { Complete } \\
\text { elementary } \\
\text { school }\end{array}$ & Married & $\begin{array}{c}\text { Hemorrhagic, } \\
10 \text { months }\end{array}$ & 28 \\
\hline S4 & 77 & $\mathrm{~F}$ & $\begin{array}{l}\text { Incomplete } \\
\text { elementary } \\
\text { school }\end{array}$ & Married & $\begin{array}{c}\text { Ischemic, } 1 \\
\text { year and } 4 \\
\text { months }\end{array}$ & 29 \\
\hline S5 & 82 & M & Illiterate & Married & $\begin{array}{l}\text { Ischemic, } 4 \\
\text { years old }\end{array}$ & 27 \\
\hline S6 & 66 & $M$ & $\begin{array}{l}\text { Incomplete } \\
\text { elementary } \\
\text { school }\end{array}$ & Married & $\begin{array}{l}\text { Ischemic, } 3 \\
\text { years old }\end{array}$ & 29 \\
\hline
\end{tabular}

Note: F/M - female/male; MMSE - Mini Mental State Examination.

\section{Categories}

The interviews lasted between 30 and 40 minutes. The analysis allowed constructing the four categories described below.

\section{You are having a stroke! - Identifying the problem}

Respondents report how, where and when stroke events occurred. These reports relate the symptoms to previous ideas about the event or to other experiences felt as well as to the diagnosis of some health professional.

I felt my leg tingle, so I started to be unable to walk, and everything I was holding in my arm fell to the floor. Then my pastor [who is a physiotherapist] said, "you are having a stroke!". They carried me and took me to the car. (S3)

Ignorance in the face of a new situation aroused feelings such as fear, anguish and anxiety. Stroke is a physically disabling disease, but it has been shown to affect other dimensions of life. Interviewee S3 was accompanied by a health professional, who recognized the signs, facilitating decision-making. 
Understanding the signs, symptoms and acting seems to be related to the meanings attributed to the experience, being an important point for the rehabilitation process. It means to say that, although rehabilitation is a process of psychomotor and/or cognitive return, it carries subjective elements from patients that interfere with this process ${ }^{(1)}$. The fact that patients have experienced similar situations previously in their lives demonstrates to facilitate decision-making. Watching someone else's ictus generates practical knowledge in the face of similar situations ${ }^{(1)}$. This can be seen in S2's speech, who witnessed a case in the family, and started to find the body's behavior strange, seeking care in an emergency room:

I felt a strange situation in my arm, the boy who was next to me said "maybe you were sitting on some circulation", then I raised my leg, I was also tingling and I wasn't listening to commands anymore. So, the bus pulled over and instead of going home I went to the emergency room. (S4)

On the other hand, there are cases where the symptoms are not recognized. This non-recognition seems to interfere with decision-making, postponing the rescue.

He started to turn everything, he was sweating, he had no pain, he had nothing, he just stunned. (S6)

S6 had a recurrence of stroke, and the first time, presented classic signs of the pathology, such as decreased strength in a hemibody and speech disorders. However, on the second episode, she reported only stunning and excessive sweating.

Having a figure as a reference in care represents security for the affected and their family members or caregivers, but the time to contact this person can interfere with the assistance. S1, when feeling ill, was not immediately rescued, as her husband, impressed, went looking for a specific physician, known to the family (husband of his mistress), which interfered with the time of referral to a specialized service ${ }^{(1)}$.

Then, instead of picking me up and going to the hospital, I don't know if he was impressed, he went there where I worked to tell my boss that I was bad, that I had fallen. (S1)

Recognizing the phenomenon is important for emergency care, but many factors have been shown to interfere with outcomes, ranging from self-knowledge of the body to the perceptions of those who are following the event.

\section{Anguish and expectations in waiting for care - Stress agents}

They took a long time to see me, to send me to the hospital [...] they took a long time to get the blood out of my head, things took a little while for me. (S3)

S3 felt harmed by the delay, showing anguish, feelings that add even more complexity to the situation. S2 reports having waited too long for application of the reversal attempt protocols:

llooked for the emergency room, where I was no longer adequately cared for. The physician saw me, like this, in the corridor [...] l even argued with him, saying that I was not complaining of a stomach ache, that I already had an affair in the family and that it was looking like a stroke, and he ironically replied "Congratulations, you, being a bricklayer, have already given your diagnosis! You will be under observation." and imposed himself, saying "end of story". Then I stayed there for 34 hours in the emergency room. (S2)

In the following speech, the patient demonstrates perceiving hesitant or mistaken attitudes by physicians, which caused delays in ictus identification, interfering with the choice of the best approaches ${ }^{(1)}$. S6 underwent examinations, however, considering her history, she may not have been properly referred and the case culminated in the impossibility of making an attempt to reverse ischemia due to thrombolysis, due to time.

He took me to the physician, hospitalized and stayed there to do a lot of electro exams, 3 electros didn't show anything, the physician said "I'm going to release". At home, when it was 2:00 in the morning, he had to call the neighbor and take me back to the hospital, did the right stroke test, CT scan, I stayed in the waiting room until I opened a room "...] I had a stroke nine years ago, but I could tell: my mouth fell out and my wife took it fast to the emergency room. (S6)

Considering the early discharge that proved to be wrong, it is speculated that, perhaps, a good listening by the physician, who considered the history of stroke declared by patients, could increase the chances of the correct direction for exams or procedures more appropriate to the case ${ }^{(1)}$. The narratives obtained allowed the identification of situations that generate suffering and stress experienced by participants.

\section{Helplessness and lack of guidance for rehabilitation after hospital discharge}

He didn't do much therapy, no. It was difficult, because the nurses couldn't take it, I was very heavy. Today, I'm thinner, you know, then my brother started to get jealous of the physician and the nurse, because they took me to put on the stretcher. (S1)

S1 values situations that limited the continuity of the psychomotor rehabilitation process, showing embarrassment for being overweight and jealous on the part of her partner, which made her more nervous. Here, we observe that the therapeutic proposal involves perceptions of the physical, emotional and family support aspects.

Patients reported a desire for multidisciplinary approaches, but referrals were restricted to drug treatment and physiotherapy. Only one patient reported referral to psychology and the speech therapy service was not mentioned.

In the case of S1, we observed that the proper referral was not the result only of compliance with protocols. It was necessary to take into account the transmitted safety, as well as the culture of patients and family members. For this reason, the partnership between health professionals and family caregivers proved to be fundamental.

There [hospital] / did [physiotherapy] [...] / already sat waiting for her, I was ready [...], I counted the hours for her to come to me. I was happy there. [...]. (S3) 
Then, outside the hospital and undergoing psychomotor and cognitive rehabilitation at an external service:

Sometimes my pastor takes me, or my husband, depending on some people as sisters in the church. I'm trying to get transportation from the city hall, but it's difficult. The social worker has not yet come here to [...] aquatic physiotherapy, occupational therapist and psychologist, I still haven't been able to make it. (S3)

S3 expresses a feeling of contentment in the treatment that was offered to her in the hospital environment. Her narrative brings positive expectations about rehabilitation. However, there is some frustration after hospital discharge.

\section{Spirituality in rehabilitation after stroke}

In view of what was going on, I can say that I am very good, it was normal. Thanks to God, it did not distort the mouth or the eyes, because I know a person who suffered this discomfort, poor thing, he was like that, his neck was crooked, he looks like that from the side [...]. (S5)

The interviewees made reference to a deity, showing gratitude for deliverance from death, from more serious consequences and from not leaving their daily activities ${ }^{(1)}$. Rehabilitation here is still understood as psychomotor and cognitive, however, with elements of spirituality, which reach patients' motivation to follow this therapeutic path. S4, before stroke, played the role of mother, grandmother, as well as caregiver for her husband; she felt responsible for several activities and showed that she did not accept the illness, and her faith seems to have been relevant, from a psychosocial point of view, in coping with the disease and in her recovery. S5 describes divine gratitude for the sequel not being similar to that of an acquaintance, who suffered changes in her face, caused by paralysis, and even unable to attend church, maintained her religious contact, adapting her shelter and bringing "worship" to the garage of her home:

I read the bible every day, before going to sleep, I have been in the Christian congregation for more than 15 years. As I am in this situation and I cannot go to church, the brothers are coming here to do the service in the garage at home. (S5)

\section{DISCUSSION}

A study with patients who suffered a stroke in Spain concluded that the levels of knowledge about the signs of the event and risk factors were low and that the experiences of previous events, in addition to the level of education, were factors that increased the probability of identifying the signs ${ }^{(18)}$. The absence of information after a stroke, or its provision at an inappropriate time by health professionals, generates feelings of anxiety, fear and low involvement in coping with sequel ${ }^{(19)}$.

Patients, as well as their family members, or those close to them, often experience insecurity, leading them to seek any forms of help instead of immediately seeking the appropriate services. The main motivations related to patients, for the delay in the use of medications and medical help, are the lack of knowledge of early symptoms of a stroke, the decision for other types of treatment other than those recommended, in addition to the preference for avoiding thrombolysis in due to its side effects ${ }^{(20)}$. The lack of knowledge about local services, how to find them, in addition to the search for alternative aids such as healers and pastors, are factors attributed to the delay in seeking care ${ }^{(21)}$.

In the "Anguish and expectations in waiting for care - Stress agents" category, it was possible to observe anxiogenic and distressing factors. Suspicions about what really happened, added to the non-acceptance of patients' discernments about the situations, apparently generated additional stressful situations in patients.

The meanings that orbit the disregard for the intuitions and feelings experienced by the patients are related to frustrations, when they realize that, even making the correct decisions to seek the emergency room, they did not receive the expected care ${ }^{(1)}$. Patients express related feelings of abandonment, frustration and having been "discarded" in similar contexts ${ }^{(21)}$.

The perception of delay in attendance was frequent both in the initial assistance and in waiting for beds, or in the team's decisions. The delay postpones decision making for the application of thrombolytic drugs, while the recommended time for this procedure is, at most, four hours and thirty minutes after stroke ${ }^{(22-23)}$. Literature reports perceptions of delays in seeking treatment after the first symptoms as well as doubts about the diagnosis and quality of care in different countries ${ }^{(9,12,21)}$.

Physicians are one of the main figures in the identification and verification of clinical condition sign, although multidisciplinary care is important for treatment ${ }^{(24)}$. During this process, it is important to respect the differences in perspectives, and the disqualification of patients' complaints by the health team is not adequate $^{(25)}$. In this sense, it is necessary to consider the obstacles that exist in the physician-patient or physician-companion relationship, which can be aggravated by the asymmetry of positions (technical language inaccessible to patients/companions), due to the lack of bond due to being a first attendance, or by a deficient physician-patient transference relationship.

McKevitt et al ${ }^{(26)}$ reported, in a study with 40 English patients who suffered a stroke, psychosocial aspects and relevant care for those affected. Among these aspects were medical care and the multidisciplinary team, information and advice, support and security.

Patients expressed the need for individualized information throughout the rehabilitation process and considered sharing power to make informed choices important ${ }^{(1)}$. In the reports, we realized that the team's information helped them to avoid magical solutions to their problems, focusing on taking an active role in their rehabilitation ${ }^{(27)}$. The results described by the subjects in this study suggest that attention and adaptation of referrals and behaviors are necessary to the social and psychological context of individuals, with clarification of the obstacles they may face in the search for professionals outside the hospital environment.

The narratives foster the reflection that there are care gaps that can bring social, economic and mental repercussions to these people and their families, being evidence of the need to provide safety and support to patients through support that is as comprehensive as possible ${ }^{(1)}$. Multidisciplinary and integrated follow-up accelerates the treatment of patients, reduces waiting time and is more cost-effective ${ }^{(28)}$. Locations with deficient health systems often present additional challenges in terms of access 
to specialized stroke assistance services and a lack of properly trained staff to provide continuity in rehabilitation ${ }^{(29)}$.

Patients who survive a stroke may not feel adequately prepared to return home, reporting a lack of sufficient information about their condition, coping strategies or advice on environmental adaptations that would help with rehabilitation. Thus, they face obstacles, such as lack of access to hospital, out-of-hospital rehabilitation and referral after discharge ${ }^{(30)}$.

Another important aspect reported by the interviewed subjects was the spirituality present in the rehabilitation path, whose relations with health are positive and possibly causal with biological and mental aspects ${ }^{(31)}$. In order to alleviate and/or minimize the feeling of uncertainty that involves diseases characterized as serious, spirituality and practices related to beliefs, faith and religion bring benefits in the health-disease-care process ${ }^{(32)}$.

Spirituality increases motivation for self-care and adaptation, reducing stress and helping to manage diseases patiently ${ }^{(33)}$. The consideration of the spiritual dimension is important to improve the understanding of the meanings of the rehabilitation process, as well as to adapt the care provided to patients, being essential for both patients and caregivers ${ }^{(34)}$. Evidence suggests that spirituality and religious practices could help reduce survivors' emotional stress, although in cases where patients attribute events to divine punishment, emotional distress may increase ${ }^{(35)}$.

The image of disruption of spiritual balance as a cause of illness often appears in social representations, while the cure would depend on the recovery of this balance, so that the care practices that privilege this aspect usually enjoy good acceptance ${ }^{(36)}$. Respecting, therefore, the symbolic of people in relation to the power of religion in their Therapeutic Itinerary, seems to be, in addition to an attitude of respect, a powerful element of therapeutic aid, insofar as they keep them motivated to care.

It is important to consider the possibility that, at times, mentions of the deities are interviewees'language addictions, not deep relationships with spirituality. However, the global observation of the framework carried out by the researcher, throughout the stages of acculturation and interviews, allowed to verify such relationships.

The paths covered in this study show singular circumstances in which the subject and other social actors participating in the process are located ${ }^{(1)}$. They are family members, caregivers and the health team with their idiosyncrasies, acting together with the health system and religious institutions, historically located in different social contexts. This complex network of situations and possibilities goes beyond the protocol's technical limits, inviting a look at the subjective issues of health relationships.

\section{Study limitations}

The fact that the main researcher has no previous experience with interviews at the time of the study's development may have limited her performance in driving and her perception of other relevant aspects of the problem, although the results presented have allowed a deeper understanding of the topic. Another limitation was the fact that the interviews were conducted at different times after stroke, sometimes long. We suggest, for future research, to conduct interviews at intervals closer to the service experiences so that participants' memory bias is reduced.

The need to observe interviewees' regionality and education stands out, and it is up to the readers of this report to consider their usefulness and plausibility in different contexts ${ }^{(14)}$.

\section{Contributions to health and public policies}

This study expands the understanding of Therapeutic Itineraries and the perceptions of patients who experienced stroke in the context of SUS. Thus, it has the potential to generate reflections in professionals who work in this line of care - which could contribute to their therapeutic practices - and in those who formulate or manage public policies, in order to improve them.

\section{FINAL CONSIDERATIONS}

Deepening the understanding of perspectives related to the therapeutic process of stroke allowed to reveal survivors' senses, meanings and attitudes, illustrating the complexity to be handled by health professionals and systems. The perceptions showed, above all, the difficulty of patients, caregivers and professionals in identifying, conducting, referencing and monitoring the event.

Patients' Therapeutic Itineraries, from their perspectives, revealed more than the trajectory in the search for health care. It was possible to reveal the experiences and difficulties faced when they need to access the services. Thus, the results displayed can support health evaluative practices that privilege the experience of being healthy or becoming ill, thus enabling the application of the principles of comprehensiveness and resolvability in health care.

\section{REFERENCES}

1. Souza AMLB. Itinerários terapêuticos na reabilitação do acidente vascular cerebral [Dissertação]. Universidade Estadual de Campinas, Faculdade de Odontologia de Piracicaba; 2020.73p.

2. Johnson W, Onuma O, Owolabi M, Sachdev S. Stroke: a global response is needed. Bull World Health Organ. 2016;94(9):634A. https://doi. org/10.2471/BLT.16.181636

3. Carvalho-Pinto BPB, Faria CDCM. Health, function and disability in stroke patients in the community. Braz J Phys Ther. 2016;20(4):355-66. https://doi.org/10.1590/bjpt-rbf.2014.0171

4. Schmidt MH, Selau CM, Soares PS, Franchi EF, Piber VD, Quatrin LB. Acidente vascular cerebral e diferentes limitações: uma análise interdisciplinar. Arq Cienc Saude UNIPAR. 2019;23(2):139-44. https://doi.org/10.25110/arqsaude.v23i2.2019.6404

5. Demétrio F, Santana E, Pereira-Santos M. O Itinerário Terapêutico no Brasil: revisão sistemática e metassíntese a partir das concepções negativa e positiva de saúde. Saúde Debate. 2019;43(spe7):204-21. https://doi.org/10.1590/0103-11042019s716 
6. Eckhardt NS, Raupp L. Itinerários terapêuticos de usuários de drogas na região sul do Brasil. Psicol Saúde Doenças. 2017;18(1):263-77. https://doi.org/10.15309/17psd180121

7. Younes S, Rizzotto MLF, Araújo ACF. Therapeutic itinerary of patients with obesity treated in high-complexity services of a university hospital. Saúde Debate. 2017;41(115):1046-60. https://doi.org/10.1590/0103-1104201711505

8. Sánchez CH, García CC, Fajardo YB, Abril JA, Forero DG, Afanador LC. Meanings of dengue, chikungunya and zika and therapeutic itineraries in a Colombian endemic municipality. Saude Soc. 2020;29(3):e190093. https://doi.org/10.1590/s0104-12902020190093

9. Krishnan S, Hay CC, Pappadis MR, Deutsch A, Reistetter TA. Stroke Survivors' Perspectives on Post-Acute Rehabilitation Options, Goals, Satisfaction, and Transition to Home. J Neurol Phys Ther. 2019;43(3):160-167. https://doi.org/10.1097/NPT.0000000000000281

10. Krishnan S, Pappadis MR, Weller SC, Fisher SR, Hay CC, Reistetter TA. Patient-centered mobility outcome preferences according to individuals with stroke and caregivers: a qualitative analysis. Disabil Rehabil. 2018;40(12):1401-9. https://doi.org/10.1080/09638288.2017.1297855

11. Naguib R, Fayed A, AIFadhliah AB, AIMansour NS, AIDakheel RM, AIQahtani RM. Awareness about stroke and proper actions to be taken; a room for improvement. J Stroke Cerebrovasc Dis. 2020;29(6):104794. https://doi.org/10.1016/j.jstrokecerebrovasdis.2020.104794

12. Jenkins C, Ovbiagele B, Arulogun O, Singh A, Calys-Tagoe B, Akinyemi R, et al. Knowledge, attitudes and practices related to stroke in Ghana and Nigeria: a SIREN call to action. PLoS One. 2018;16;13(11):e0206548. https://doi.org/10.1371/journal.pone.0206548

13. Reis C, Faro A. Repercussões psicológicas após um acidente vascular cerebral (AVC): uma revisão de literatura. Psicol Saúde Doenças. 2019;20(1):16-32. https://doi.org/10.15309/19psd200102

14. Faria-Schützer DB, Surita FG, Alves VLP, Bastos RA, Campos CJG, Turato ER. Seven steps for qualitative treatment in health research: the Clinical-Qualitative Content Analysis. Cienc Saude Colet. 2021;26(1):265-274. https://doi.org/10.1590/1413-81232020261.07622019

15. Tong A, Sainsbury P, Craig J. Consolidated criteria for reporting qualitative research (COREQ): a 32-item checklist for interviews and focus groups. Int J Qual Health Care. 2007;19(6):349-57. https://doi.org/10.1093/intqhc/mzm042

16. Instituto Brasileiro de Geografia e Estatística (IBGE). Cidades e Estados [Internet]. 2021 [cited 2021 Apr 03]. Available from: https://www.ibge. gov.br/cidades-e-estados/sp/piracicaba.html

17. Hennink MM, Kaiser BN, Weber MB. What influences saturation? estimating sample sizes in focus group research. Qual Health Res. 2019;(10):1483-96. https://doi.org/10.1177/1049732318821692

18. Soto-Cámara R, González-Bernal JJ, González-Santos J, Aguilar-Parra JM, Trigueros R, López-Liria R. Knowledge on signs and risk factors in stroke patients. J Clin Med. 2020;9(8):2557. https://doi.org/10.3390/jcm9082557

19. Della Vecchia C, Préau M, Carpentier C, Viprey M, Haesebaert J, Termoz A, et al. Illness beliefs and emotional responses in mildly disabled stroke survivors: a qualitative study. PLoS One. 2019;14(10):e0223681. https://doi.org/10.1371/journal.pone.0223681

20. Baatiema L, Otim ME, Mnatzaganian G, de-Graft Aikins A, Coombes J, Somerset S. Health professionals' views on the barriers and enablers to evidence-based practice for acute stroke care: a systematic review. Implement Sci. 2017;5;12(1):74. https://doi.org/10.1186/s13012-017-0599-3

21. Pindus DM, Mullis R, Lim L, Wellwood I, Rundell AV, Abd Aziz NA, et al. Stroke survivors' and informal caregivers' experiences of primary care and community healthcare services: a systematic review and meta-ethnography. PLoS One. 2018;13(2):e0192533. https://doi.org/10.1371/ journal.pone.0192533

22. Silva IFG, Neves CFS, Vilela ACG, Bastos LMD, Henriques MILS. Viver e cuidar após o acidente vascular cerebral. Rev Enf Ref. 2016;serIV(8):103-11. https://doi.org/10.12707/RIV15047

23. Pereira MSM, Guedes HM, Oliveira LMN, Martins JCA. Relação entre o Sistema de Triagem de Manchester em doentes com AVC e o desfecho final. Rev Enf Ref. 2017;serIV(13):93-102. https://doi.org/10.12707/RIV16079

24. Anderle P, Rockenbach SP, Goulart BNG. Post-stroke rehabilitation: identification of speech-language disorders signs and symptoms by physicians and nurses in Primary Health Care. CoDAS. 2019;31(2):e20180015. https://doi.org/10.1590/2317-1782/20182018015

25. Castelhano LM, Wahba LL. O discurso médico sobre as emoções vivenciadas na interação com o paciente: contribuições para a prática clínica. Interface (Botucatu). 2019;23:e170341. https://doi.org/10.1590/interface.170341

26. McKevitt C, Redfern J, Mold F, Wolfe C. Qualitative Studies of Stroke. Stroke. 2004;35(6):1499-505. https://doi.org/10.1161/01. STR.0000127532.64840.36

27. Maclean N. Qualitative analysis of stroke patients' motivation for rehabilitation. BMJ. 2000;3 21(7268):1051-4. https://doi.org/10.1136/ bmj.321.7268.1051

28. Abdul Aziz AF, Mohd Nordin NA, Muhd Nur A, Sulong S, Aljunid SM. The integrated care pathway for managing post stroke patients (iCaPPS $\odot$ ) in public primary care Healthcentres in Malaysia: impact on quality adjusted life years (QALYs) and cost effectiveness analysis. BMC Geriatr. 2020;20(1):70. https://doi.org/10.1186/s12877-020-1453-z

29. Abdul-Aziz AF, Mohd-Nordin NA, Ali MF, Abd-Aziz NA, Sulong S, Aljunid SM. The integrated care pathway for post stroke patients (iCaPPS): a shared care approach between stakeholders in areas with limited access to specialist stroke care services. BMC Health Serv Res. 2017;17(1):35. https://doi.org/10.1186/s12913-016-1963-8

30. Govender P, Naidoo D, Bricknell K, Ayob Z, Message H, Njoko S. 'No one prepared me to go home': Cerebrovascular accident survivors' experiences of community reintegration in a peri-urban context. Afr J Prim Health Care Fam Med. 2019;11(1):e1-e8. https://doi.org/10.4102/ phcfm.v11i1.1806 
31. Moreira WC, Nóbrega MPSS, Lima FPS, Lago EC, Lima MO. Efeitos da associação entre espiritualidade, religiosidade e atividade física na saúde/saúde mental: revisão sistemática. Rev Esc Enferm USP. 2020;54:e03631. https://doi.org/10.1590/s1980-220x2019012903631

32. Lavorato Neto G, Rodrigues L, Silva DARD, Turato ER, Campos CJG. Spirituality review on mental health and psychiatric nursing. Rev Bras Enferm. 2018;71(Suppl-5):2323-33. https://doi.org/10.1590/0034-7167-2016-0429

33. Azar NS, Radfar M, Baghaei R. Spiritual self-care in stroke survivors: a qualitative study. J Relig Health. 2020. https://doi.org/10.1007/ s10943-020-01030-7

34. Gibbs LAL, Anderson MI, Simpson GK, Jones KF. Spirituality and resilience among family caregivers of survivors of stroke: a scoping review. Neuro Rehabil. 2020;46(1):41-52. https://doi.org/10.3233/NRE-192946

35. Park CL, Holt CL, Le D, Christie J, Williams BR. Positive and Negative Religious Coping Styles as Prospective Predictors of Well-Being in African Americans. Psychol Relig Spirit. 2018;10(4):318-326. https://doi.org/10.1037/rel0000124

36. Coelho MTAD, Carvalho VP, Porcino C. Representações sociais de doença, usos e significados atribuídos às Práticas Integrativas e Complementares por universitários. Saúde Debate. 2019;43(122):848-62. https://doi.org/10.1590/0103-1104201912215 